\title{
Determinant factors of village fund policy implementation in Selayar, South Sulawesi Province
}

\author{
Muhammad Guntur \\ Universitas Negeri Makassar \\ Makassar, Indonesia
}

\author{
Muhammad Nur Yamin \\ Universitas Negeri Makassar \\ Makassar, Indonesia
}

\begin{abstract}
Village funds are expected to be the solution to improving the service and village governance. The research was aimed to analyze the various determinant factors that contribute to funding policy implementation in Bontomatene district, Selayar, South Sulawesi Province. This research is both descriptive and qualitative. It is focused on the implementation of village fund policy from the aspects of communication, resources, disposition and bureaucratic structure. Data collection techniques include observation, interview, and documentation. Data were analyzed using an interactive model. The results showed that village fund policy implementation in Bontomatene District was still weak on an aspect of communication as the rules issued by the central government. It still lacked consistent applications due to not clear and less assertive translations of rules at operational levels, even though information delivery was good enough in terms of its short-track communication bureaucracy. The resources aspects were also weak, especially the human resource competencies which were not adequate compared to their duties.
\end{abstract}

Keywords—village fund; policy; service

\section{General InSTRUCTIONS}

The success of public policy that has been defined by the policymaker is determined in the implementation process. Van Meter \& Van Horn formulated implementation as "those actions by public or private individuals and groups are directed at the achievement objectives outlined in prior policy decisions"[1]. Grindle and Thomas argued that the task of implementation be to establish a linkage that facilitates the realization of strategic objectives as the results of government activities[2]. According to Birkland, implementing policies requires a top-down approach or a bottom-up approach [3]. The top-down approach is a centralized type and departed from the perspective that political decisions (policies) that determined by the policymakers should be carried out by an administrator or bureaucrat at the street level bureaucrat. Bottom-up approach highlights the implementation of policies that formulated from community initiation.

The presence of village funds that sourced from revenues and expenditures budget earmarked for villages to fund government activities, implementation of development, social fostering, and community development. As a solution it has been initiated by the central government for the improvement of village services, and its governance, it needed requiring an orderly good management, obedient to provisions of legislation, efficient, economical, effective, transparent and accountability with regard to justice and propriety, as well as interests of the local community. The purpose of this study was to analyze various determinants that contribute to success in the implementation of village fund policy.

Sabatier and Mazmanian, argued that policy implementation is consisted by following elements [4]: a) implementing elements; b) program to be implemented; and c) the target group. Successful implementation of policy can be seen from the process and achievement of the final results (outputs); goals are achieved or not. The criteria for measuring the success of policies implementation based on three perspectives, namely: 1) perspective of compliance of lower bureaucracy to upper bureaucracy; 2) perspective of smooth running routine and lack of problems; 3) implementation perspective that leads to the satisfaction of all parties, especially the expected beneficiary groups [5].

\section{RESEARCH METHOD}

This is a descriptive research that based on qualitative approach. The study was undertaken in the villages in Bontomatene district, Selayar Islands Regency. The research focus was stated on the implementation of village fund policy regarding the concept of Edwards III \& Wayne which argued that determinants of the success of policy implementation be communication, resources, disposition and bureaucratic structure [6]. Data collection techniques employed include observation, interview, and documentation. Data analysis technique was based on the interactive model of Miles, Huberman, \& Saldana [7]. Data verification was done with two procedures: triangulation of information and member checking.

\section{RESUlt AND Discussion}

Each policy implementation that has been translated into programs or projects will be followed by physical actions. Table 1 shows that Result summary of interview and observation on village fund implementation research.

According to Edwards III and Wayne, factors that influence the success or failure of policy implementation, are; communication, resources, disposition and bureaucratic structure [6]. These factors interact with one another. 
TABLE I. RESULT SUMMARY OF INTERVIEW AND OBSERVATION ON VILLAGE FUND IMPLEMENTATION RESEARCH

\begin{tabular}{|c|c|c|c|}
\hline \multicolumn{4}{|c|}{ Research Result and Discussion } \\
\hline Dimension & Indicators & Assessment & Conclusion \\
\hline \multirow[t]{3}{*}{ Communication } & Transmission & Fast information & \multirow[t]{3}{*}{ Weak communication } \\
\hline & Consistency & Confusing & \\
\hline & Clearness & Slow implementation instruction & \\
\hline \multirow[t]{3}{*}{ Resources } & Staff capability & Non-sufficient capabilities & \multirow[t]{3}{*}{ Weak resources } \\
\hline & Authority & Limited authorities for implementation & \\
\hline & Structure and infrastructure & $\begin{array}{l}\text { Availability of structure and infrastructure } \\
\text { (SIMDA) }\end{array}$ & \\
\hline \multirow[t]{3}{*}{ Disposition } & Attitude & $\begin{array}{l}\text { Intention of implemented to complete the } \\
\text { policy }\end{array}$ & \multirow[t]{3}{*}{ Strong Disposition } \\
\hline & Willingness & Preserving the goals consistency & \\
\hline & Commitment & Strong to complete the policy & \\
\hline \multirow[t]{3}{*}{ Bureaucratic structure } & Standard Operation Procedure & SOP guided the actions of implementer & \multirow{3}{*}{$\begin{array}{l}\text { Strong } \\
\text { structure }\end{array}$} \\
\hline & Organization fragmentation & Distribution of duty was still overlap & \\
\hline & Program coordination & $\begin{array}{l}\text { Job distribution, authority delegation, } \\
\text { duty fragmentation }\end{array}$ & \\
\hline
\end{tabular}

\section{A. Communication}

Communication or socialization of policy provides an opportunity for the community. With the socialization, then the new norms grow in line with the implementation of policy. Communications policy makes it easier for the implementor and the community to work together in achieving goals.

Communication on the implementation of village fund policy was analyzed on three aspects, namely: transmission, clarity, and consistency. An aspect of transmission was found quite well which indicated by its short-bureaucracy, delivery of policy information directly to the implementing units through face to face communication channels.

Another case showed the weakness of preparation of derived rules from government regulations No.60 year 2014 at the operational level, implementation of a policy rule is less consistent and less firm, and, though, the arrangement was correctly following the reporting standards. To play its role, actors involved in the implementation of policies should have enough information. Hoogerwerf argued that communications received by the policy implementers must be clear and unambiguous so that no differences of perception occurred among government officers [8].

\section{B. Resources}

Organization resource, in carrying out a policy, covers the staffs (quantity and quality), authority, and sufficient structures/infrastructures. The intellectual capacity of human resources in villages is commonly not adequate compared to the tasks and duties, the implementation teamwork has not quite competent in their field, the authority of implementing units were frequently intervened by upper-level government agencies, and low availability of structures and infrastructure to support policy implementation of the village fund.

\section{Disposition}

Disposition is defined as a tendency, desire or agreement of implementer to implement a policy. The result showed that attitude of acceptance, willingness to succeed and commitment to policy implementation at street level bureaucracy was strong. Intensive interaction between the determinants of interest to the action executor, and the existence of strong desire to run the governance guidelines workflow in implementation and solving problems that arise in policy implementation. Based on this understanding, the main factors affecting the performance of policy implementation is the individual's ability to perform the job, the level of effort devoted, and organizations support [6].

Based on the opinion of Edwards III \& Wayne, effective policy implementation will require the policy implementers to not only know what to do but also have the ability and willingness to implement them [6]. Disposition of policy implementer will affect the policy performance as when the implementation of policies is based on attitude, desire and commitment to implement policies, successful implementation of policies will be even greater.

\section{Bureaucratic structure}

The structure of a policy implementation requires the existence standardized operating procedure that governs the flow of policy implementation. It includes operational procedures, fragmentation, and coordination. The study concluded that village fund policies had been implemented according to operational standards, the fragmentation of authority was clear but not yet decisively in the implementation, and there were still takeovers on responsibilities and activities between implementing units, and coordination on a number of funds under management, planning, implementing, and reporting was done according to the procedure.

The bureaucratic structure is necessary for the implementation of policies to achieve desired outcomes regarding the required standards and line with previous policy. Edwards III \& Wayne argued that characteristics that can boost the performance of bureaucratic structures towards better achievements be the application of the Standard Operating Procedures [6]. This is also supported by Robbins that justifies the structure factor as one of the elements determining the effectiveness of the organization's performance [9]. 


\section{CONCLUSIONS}

Implementation of village fund policy has not been carried out according to the program's objectives in the Bontomatene district, Selayar Islands Regency, due to limited resources and non-sufficient program communication. For two years implementation, village fund policy was made possible by the strong commitment of the implementers and bureaucratic structures that went well. Moreover, weak communication was due to the slow manufacture of technical implementation guidelines from higher regulations at the district level. Weak resource aspects were also found on technical capabilities of staff in implementation activities, planning authority at village level which intervened by regency level authorities. In addition, strong bureaucratic structures for compliance with the standard operating procedures and program coordination were good, although the fragmentation of the implementing units was weak. Disposition program has been strong from the aspect of attitude, the willingness, and commitment to policy implementation of village fund policy at implementer level.

\section{References}

[1] D. S. Van Meter and C. E. Van Horn, "The policy implementation process: A conceptual framework," Adm. Soc., vol. 6, no. 4, pp. 445$488,1975$.

[2] M. S. Grindle and J. W. Thomas, Public choices and policy change: the political economy of reform in developing countries. JHU Press, 1991.

[3] T. A. Birkland, An introduction to the policy process: Theories, concepts and models of public policy making. Routledge, 2014.

[4] P. Sabatier and D. Mazmanian, "The implementation of public policy: A framework of analysis," Policy Stud. J., vol. 8, no. 4, pp. 538-560, 1980.

[5] R. B. Ripley and G. A. Franklin, Policy Implementation and Bureaucracy. Chicago, United States: Dorsey Press, 1986.

[6] G. C. Edwards III and S. J. Wayne, Presidential leadership: Politics and policy making. Cengage Learning, 2013.

[7] M. B. Miles, A. M. Huberman, and J. Saldana, Qualitative Data Analysis: A Methods Sourcebook, 3rd ed. United States of America: Sage Publications, 2014.

[8] A. Hoogerwerf, "Overheidsbeleid," Alphen aan den Rijn Samsom, 1978.

[9] S. P. Robbins, "Teori Organisasi: Struktur, Desain dan Aplikasi Terjemahan, PT. Prenhallindo, Jakarta," Broad scope Timeliness Agreg. Integr., 1996. 